\title{
The Effectiveness of Behavioral Counseling with Self- Management Technique in Improving Endurance Personality
}

\author{
I Ketut Gading ${ }^{1}$, Kade Sathya Gita Rismawan ${ }^{2}$, Gede Nugraha Sudarsana ${ }^{3}$ \\ \{ketutgading35@gmail.com ${ }^{1}$, sathyagitarisma@gmail.com² ${ }^{2}$ nugraha@undiksha.ac.id $\left.{ }^{3}\right\}$ \\ Universitas Pendidikan Ganesha, Indonesia
}

\begin{abstract}
This study aimed to determine the effectiveness of behavioral counseling with selfmanagement technique in improving endurance personality. This research was quasiexperimental research with a pretest-posttest control group design. The participants in this research were students of XI IPA4 of SMA Laboratorium Undiksha who have low endurance personalities. The classes were chosen randomly from 9 classes of $11^{\text {th }}$ grade students, who were the population of this study. The data collection method used in this research was the endurance personality questionnaire, in order to collect the data about the endurance personality character. The data analysis for hypothesis testing was done using an independent sample t-test. Based on the t-test, the t-coefficient was 3.959 with a significance level of 0.001 . Therefore, the behavioral counseling with self-management techniques effectively improved endurance personality character.
\end{abstract}

Keywords: Behavioral Counseling, Self-Management, Endurance Personality

\section{Introduction}

The rapid development of science and technology has brought great changes to almost all aspects of human life. These changes are often unpredictable, giving birth to tensions, disappointments, frustrations, and even suicides. Corruptors who are currently on trial or even in prison may not have suspected that what was done the other day would have a very painful effect.

In such conditions, each person must have a way of thinking, feeling, and behaving in such a way that they are not stressed or frustrated when facing a life full of competition. In other words, each person must have a mature personality when facing life if they want to not be swayed by changes that are often unexpected. One of the most important personality characters that someone needs to have so that they remain stable in the face of life is the endurance to face obstacles or trials [1]

Endurance personality: working on the task until it is finished, holding down the work to completion, and working hard on a task (Murray in Hall \& Lindzey, 1970). In order to increase the characteristics of endurance personality, one of the efforts that can be done is by following behavioral counseling [2] 
According to Corey, behavioral therapy or counseling has been used to treat a variety of psychological disorders among different client populations. Behavioral counseling aims to improve one's skills so that they have more options to choose from when responding. By interfering with debilitating behavior and limited choices, people are free to choose from possibilities that were not available beforehand, thereby increasing their individual freedom [3]

The effectiveness of behavioral counseling for the intervention of several personality characters, among others, was found by Asri, Suarni, and Arum to be that, together with positive reinforcement techniques, it effectively infused the confidence in students of class VIII Singaraja Middle School 2 academic year 2013/2014 [4]. Gading, Nisa, and Lestari found that behavioral counseling with modeling techniques effectively minimizes the tendency of aggressive behavior of high school students [5]. Prabowo and Cahyawulan state counseling using a behavioral approach is an effective counseling approach to behavior modification, namely suppressing maladaptive behavior and increasing adaptive behavior [6].

One behavioral counseling technique that is often used for behavioral interventions is behavioral counseling with self-management techniques, namely counseling techniques carried out by helping counselees manage themselves with steps: (1) goal setting, (2) self-monitoring, (3) stimulus-control, (4) self-evaluation, and (5) self-reinforcement [3]

The effectiveness of behavioral counseling with self-management techniques for intervention some personality trait found by Monica and Gani who discovered that behavioral counseling services with self-management techniques can develop learning responsibilities in class XI students of SMA Al-Azhar 3 Bandar Lampung Academic Year 2016/2017 [7]. Megantari, Antari, and Dantes found that behavioral counseling with self-management techniques managed to improve the discipline of learning from low categories to very high categories [8]. Setiawan, Sedanayasa, Suranata (2013) found that the application of behavioral counseling and selfmanagement strategies successfully improved SMA Negeri 2 Singaraja students' independence in decision making [9]. Indryaningsih, Dharsana, and Suranata found that the application of behavioral counseling with self-management techniques succeeded in enhancing the motivation in VIII B4 Students of SMP Negeri 4 Singaraja [10]. Suwardani, Dharsana, and Suranata found that the implementation of behavioral counseling with self-management techniques succeeded in improving the self-concept of class VIII B3 students at SMP Negeri 4 Singaraja [11].

\section{Method}

This research was an experimental study using a nonequivalent pretest-posttest control group design. The participants were students of the Senior High School who were identified as having low endurance personality characters. The sample was chosen because the students with low endurance personality were treated more urgently than others (students with intermediate and high endurance personality). Eight students were included in the experimental group and 8 students were included in the control group. The treatment of counseling behavioral with self-management techniques with steps (1) goal setting, (2) self-monitoring, (3) stimulus-control, (4) self-evaluation, and (5) self-reinforcement carried out to improve 3 indicators of endurance personality. The indicators consist of holding the task to completion (until the time is up), holding 
the job to completion, and working hard on a task. Each indicator needs 3 times counseling to finish the steps. Counseling is also accompanied by homework to conduct behavior according to endurance personality indicators and the results are reported in a diary. Data on endurance personality was collected by endurance personality questionnaire. To test the hypothesis, the data was analyzed using the t-test to discover endurance personality differences between experimental and control group.

\section{Results And Discussion}

The result of the pretests and posttests endurance personality of students in the experimental and control groups is shown in the following table 01 :

Table 1. Personality Data Endurance pretest and posttest results Experiment Group and Control Group

\begin{tabular}{cccccc}
\hline \multicolumn{3}{c}{ Experimental Group } & \multicolumn{3}{c}{ Control group } \\
Name & Pretest & Posttest & Name & Pretest & Posttest \\
\hline & & & & & \\
GWU & 80 & 119 & AH & 111 & 113 \\
IGNANK & 109 & 120 & CJS & 114 & 117 \\
KA & 107 & 123 & GAWD & 113 & 118 \\
MFT & 109 & 123 & IGAGP & 111 & 117 \\
NKMM & 107 & 119 & KAW & 112 & 118 \\
NLPLLD & 96 & 119 & MPV & 98 & 106 \\
NMS & 113 & 127 & RW & 110 & 112 \\
PND & 109 & 124 & YNA & 111 & 116 \\
Total & 830 & 964 & Total & 880 & 917 \\
Average & 103.75 & 120.5 & Average & 110 & 114,62 \\
\hline
\end{tabular}

Table 01 shows an increase in the score from the score of the pretests to the ones of the posttests. This increase is fairly high in the experimental group, with average pretest results obtained in the amount of 103.75 and average posttest results equal to 120.5. Table 01 also shows a slight increase in the score from the pretest score to the posttest one in the control group, with the average results of the pretest being equal to 110 and the results of the average posttest being equal to 114.62. (Raw data is available at https://osf.io/23vrw) [12] with variable description available at https://osf.io/6jvfz [13] 
Based on the data from the pretest and posttest given to the experimental group and the control group above, then a graph of the average pretest and posttest results can be presented in the experimental group and the control group, such as the 01 chart below:

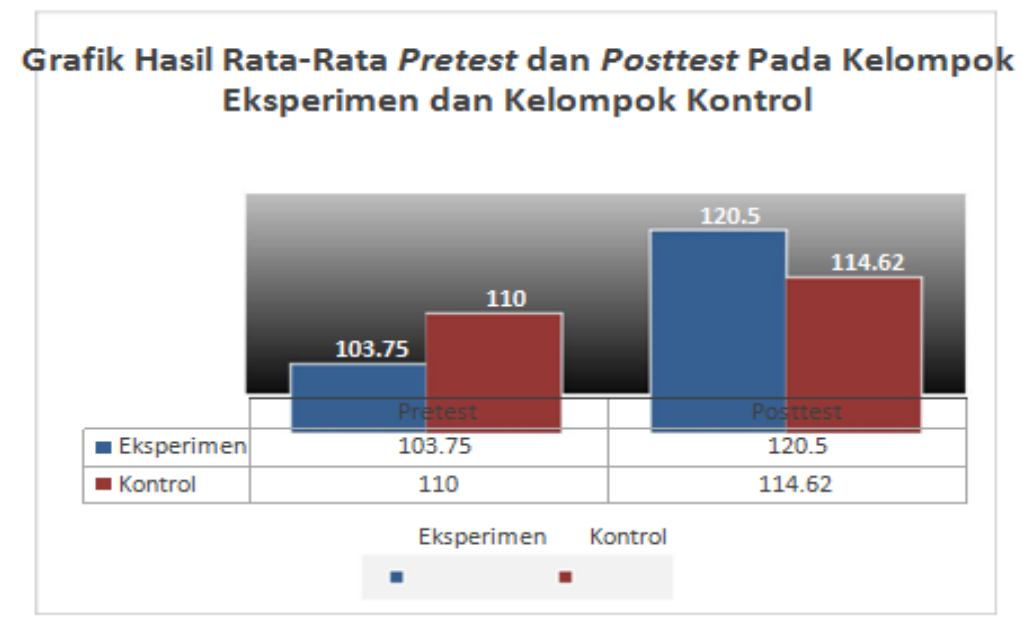

Fig 1. The average results of the pretest and posttest in the experimental group and control group

Based on the graphs of the average pretest and posttest results in the experimental group and the control group listed in Figure 01 above, it can be seen that the average posttest results in the experimental group given treatment with behavioral counseling with selfmanagement techniques are higher than in the control group that was not given a treatment with behavioral counseling with self-management techniques. With this, it can be predicted that the application of behavioral counseling to self-management techniques is effective to improve endurance personality of students.

To find out whether the independent variable is effective in increasing the dependent variable, then the next t-test is performed using the help of the SPSS-PC 20.0 for Windows program. The results of the data analysis using the t-test found a $t$ value of 3.959 with a significance level of 0,001 (the complete analysis results are available at https://osf.io/gbn45) [14]. The significance value obtained is less than $0.05(0.001<0.05)$. This means that counseling behavioral with selfmanagement techniques is effective to improve endurance personality.

The results of the study confirm that behavioral counseling is not only effective in intervening in various behaviors but that effective interventions for personality characteristics such as personality character manifest themselves in behavior.

The results of this study are relevant to the results of previous studies as disclosed in the introduction, such as Monica and Gani who found that behavioral counseling services with selfmanagement techniques can develop learning responsibilities in class XI students of Al-Azhar 3 
High School Bandar Lampung Academic Year 2016/2017[7]. Megantari, Antari, and Dantes (2014) found that behavioral counseling with self-management techniques succeeded in increasing the discipline of learning from low categories to very high categories [8]. Setiawan, Sedanayasa, and Suranata found that the implementation of behavioral counseling with self-management strategies succeeded in increasing five times the independence of students taking decisions at Singaraja 2 Public High School Academic Year2012/2013[9]. Indryaningsih, Dharsana, and Suranata (2014) found that the application of behavioral counseling with self-management techniques succeeded in enhancing student motivation [10]. Suwardani, Dharsana, and Suranata (2014) found that the implementation of behavioral counseling with self-management techniques succeeded in improving the self-concept [11].

\section{Conclusions And Suggestions}

Based on the results, it can be concluded that behavioral counseling with selfmanagement techniques is effective to improve the personality characteristics of endurance of high school students.

Based on the findings of the study, it was suggested that counseling teachers apply behavioral counseling with self-management techniques to improve endurance personality character among the students they care for.

\section{Reference}

[1] I G. Ratnaya, Dampak Negatif Perkembangan Teknologi Informatika dan Komunikasi dan Cara Antisifasinya, JPTK Vol 8, No 1 (2011)

[2] P. Y., Noviyanti, G. Sedanayasa, I K. Dharsana, Perbedaan Pengaruh Konseling Behavioral dengan Teknik Token Economy dan Shaping untuk Meningkatkan Self-Endurance Siswa Kelas X SMA Negeri 3 Singaraja, Jurnal Ilmiah Bimbingan Konseling Undiksha Vol 4, No 1 (2016)

[3] G. Corey, Theories and Practice of Counseling and Psychotherapy, Belmont:_Thomson Higher Education (2009)

[4] N. L. Asri, N. K. Suarni, D. A. W. M. Putri, Efektivitas Konseling Behavioral dengan Teknik Positive Reinforcement untuk Meningkatkan Rasa Percaya Diri dalam Belajar pada Siswa Kelas VIII SMP Negeri 2 Singaraja Tahun Pelajaran 2013/2014, Jurnal Ilmiah Bimbingan Konseling Undiksha, Vol 2, No 1 (2014) [5] Gading, I K., Nisa, U., Lestari, LPS Effectiveness of Behavioral Counseling Modeling and Counseling Techniques Transactional Analysis Role Playing Techniques to Minimize the Trend of Aggressive Behavior of High School Students. Journal Kajian Bimbingan Konseling, ISSN 25033417 (online), ISSN 2548-4311 (print) Vol 2, No 4 (2017)

[6] A. S. Prabowo, W. Cahyawulan, Pendekatan Behavioral: Dua Sisi Mata Pisau, Insight: Jurnal Bimbingan Konseling, Volume 5 (2016)

[7] M. A. Monica, R. A. Gani, Effectiveness of Behavioral Counseling Services with Self-Management Techniques to Develop Learning Responsibilities in Class XI Students of Al-Azhar 3 High School Bandar Lampung Academic Year 2015/2016. Publication manuscript. Lampung: Tarbiyah and Teacher Training Faculty, Raden Intan IAIN (2016)

[8] N. P. Megantari, N. N. M. Antari, N. Dantes, Application of Behavioral Counseling with Self Management Strategies to Improve Learning Discipline of Students in Class X Mia-4 Singaraja 3 High 
School 2013/2014 Academic Year. Jurnal Ilmiah Bimbingan Konseling Undiksha, Volume 2 number 1 tahun (2014)

[9]. G. D. Setiawan, G. Sedanayasa, K. Suranata Application of Behavioral Counseling with Self Management Strategies to Increase Independence in Taking Student Decision X5 Singaraja 2 High School 2/2012 Academic Year, Jurnal Ilmiah Bimbingan Konseling Undiksha, Volume 1 Number 1 (2013)

[10]. N. L. P. Indryaningsih, I K. Dharsana, K. Suranata, Application of Behavioral Counseling with Self Management Techniques to Improve Student Motivation in Secondary VIII B4 Singaraja Public Middle School 4. Jurnal Ilmiah Bimbingan Konseling Undiksha, Volume 2 number 1 tahun (2014)

[11] N. K. P. Suwardani, I K. Dharsana, K.Suranata, Application of Behavioral Counseling with Self Management Techniques to Improve the Self Concept of Class VIII B3 Students at Singaraja 4 Middle School Jurnal Ilmiah Bimbingan Konseling Undiksha, Volume 2 number 1 Tahun (2014)

[12] I K. Gading, Dataset (Rowscore of Endurance Personality).sav (Version: 1) available on https://osf.io/23vrw

[13] I K. Gading, Dataset (Variable Description).docx (Version: 1), available on https://osf.io/6jvfz

[14] I K. Gading, Dataset the result of t test1.spv.docx (Version: 1) available on https://osf.io/gbn45 